\title{
ANALISA HUBUNGAN FAKTOR PERSONAL DAN MANAJEMEN K3 TERHADAP TINDAKAN TIDAK AMAN DAN KECELAKAAN KERJA PADA PROYEK KONSTRUKSI INDONESIA SATU TOWER
}

\author{
Agus Komarudin $^{1}$, Kholii ${ }^{2}$, Toto Hardiyanto ${ }^{3}$
}

${ }^{1,2}$ Universitas Sahid Indonesia, ${ }^{3}$ Cranfield University, United Kingdom

Email: samuderabiru77@gmail.com, kholillppm@gmail.com, toto.h.subagyo@gmail.com

\begin{tabular}{|c|c|}
\hline & BSTRAK \\
\hline Dite & \multirow{16}{*}{$\begin{array}{l}\text { Tujuan dari penelitian yaitu untuk mengetahui dan menganalisis } \\
\text { pengaruh variabel faktor personal dan manajemen K3 terhadap } \\
\text { kecelakaan kerja melalui tindakan tidak aman pada proyek konstruksi } \\
\text { indonesia satu Tower PT. Bintai Kindenko Engineering Indonesia. } \\
\text { Sampel dalam penelitian sebanyak } 100 \text { orang. Alat analisis data } \\
\text { menggunakan Smart PLS } 3.0 \text { dengan menguji inner model, outer model } \\
\text { dan pengujian hipotesis. Hasil penelitian menunjukkan bahwa variabel } \\
\text { faktor personal berpengaruh secara signifikan terhadap tindakan tidak } \\
\text { aman. variabel manajemen K3 terbukti berpengaruh signifikan terhadap } \\
\text { tindakan tidak aman. Variabel faktor personal terbukti berpengaruh } \\
\text { signifikan terhadap kecelakaan kerja variabel manajemen k3 tidak } \\
\text { terbukti berpengaruh signifikan terhadap kecelakaan kerja. Variabel } \\
\text { tindakan tidak aman terbukti berpengaruh secara signifikan terhadap } \\
\text { kecelakaan kerja. Variabel faktor personal terbukti berpengaruh } \\
\text { signifikan terhadap kecelakaan kerja melalui tindakan tidak aman dan } \\
\text { variabel manajemen K3 terbukti berpengaruh signifikan terhadap } \\
\text { kecelakaan kerja melalui tindakan tidak aman pada proyek konstruksi } \\
\text { Indonesia Satu Tower PT. Bintai Kindenko Engineering Indonesia. }\end{array}$} \\
\hline & \\
\hline & \\
\hline & \\
\hline & \\
\hline & \\
\hline & \\
\hline & \\
\hline & \\
\hline & \\
\hline & \\
\hline & \\
\hline & \\
\hline & \\
\hline & \\
\hline & \\
\hline
\end{tabular}

\section{ABSTRACT}

The purpose of the study is to find out and analyze the influence of personal factors and K3 management variables on work accidents through unsafe actions on indonesia construction project one Tower PT. Bintai Kindenko Engineering Indonesia. The sample in the study was 100 people. Data analysis tools use Smart PLS 3.0 by testing inner models, outer models and hypothesis testing. The results showed that personal factor variables had a significant effect on unsafe actions. K3 management variables have been shown to have a significant effect on unsafe actions. Personal factor variables proved to have a significant effect on work accidents $K 3$ management variables were not shown to have a significant effect on work accidents. Unsafe action variables were shown to significantly affect work accidents. Personal factor

Keywords:

Personal Factors, K3 Management; Unsafe Actions; Accidents Work variables proved to have a significant effect on work accidents through unsafe actions and K3 management variables proved to have a significant effect on work accidents through unsafe actions on the Indonesia One Tower PT construction project. Bintai Kindenko Engineering Indonesia.

$\begin{array}{ll}\text { How to cite: } & \text { Komarudin, A., Kholil, Toto Hardiyanto (2022). Analisa Hubungan Faktor Personal dan Manajemen } \\ & \text { K3 Terhadap Tindakan Tidak Aman dan Kecelakaan Kerja pada Proyek Konstruksi Indonesia Satu } \\ & \text { Tower, Jurnal Syntax Transformation, 3(1). https://doi.org/10.46799/jst.v3i1.488 } \\ \text { E-ISSN: } & 2721-2769 \\ \text { Published by: } & \text { Ridwan Institute }\end{array}$




\section{Pendahuluan}

Pada tahun 2011 di Indonesia angka kecelakaan kerja sangat tinggi hingga mencapai 99,491 kasus data ini didapat dari Jamsostek. Jumlah tersebut meningkat dibanding tahun- tahun sebelumnya. Sebanyak 83.714 kasus tercatat di tahun 2007 dan tahun 2008 tercatat 94.736 kasus, sedangkan di tahun 2009 tercatat 96.314 kasus dan 98.711 kasus tercatat di tahun 2010. Pada tahun 2017 tercatat 123.000 kecelakaan dan di tahun 2018 meningkat menjadi 153.000 kecelakaan (Ramli, 2010).

Tabel 1

Data Kecelakaan Kerja di Indonesia Tahun 2010-2017

\begin{tabular}{cll}
\hline Tahun & Kecelakaan & Meninggal \\
\hline 2010 & 98.712 & 2.191 \\
\hline 2011 & 94.491 & - \\
\hline 2012 & 103.074 & 2.332 \\
\hline 2013 & 103.235 & 2.338 \\
\hline 2014 & 105.383 & 2.375 \\
\hline 2015 & 110.285 & 2.308 \\
\hline 2016 & 105.182 & 2.382 \\
\hline 2017 & 123.000 & - \\
\hline \multicolumn{2}{c}{ Sumber: BPJS }
\end{tabular}

Dari kecelakaan tersebut mencakup seluruh perusahaan yang terdaftar menjadi anggota jamsostek dengan jumlah peserta sekitar 7 juta orang atau sekitar $10 \%$ dari seluruh pekerja di Indonesia. Dengan demikian angka kecelakaan kerja mencapai 930 kasus untuk setiap 100.000 pekerja setiap tahun. Oleh karena itu jumlah kecelakaan kerja secara keseluruhan diperkirakan jauh lebih besar (Ramli, 2010).

Menurut (PI et al., 2017) masalah kecelakaan kerja yang sering terjadi saat ini banyak menimpa pekerja proyek konstruksi gedung bertingkat tinggi atau sering disebut sebagai high rise building yang pembangunannya banyak dikerjakan di beberapa kota besar, seperti kota metropolis di Jakarta dan kota-kota besar lainnya di Indonesia (Djatmiko, 2016). Seiring banyaknya pembangunan proyek-proyek konstruksi gedung bertingkat maka semakin tinggi pula potensi kecelakaan kerja, risiko kecelakaan kerja yang paling tinggi adalah pembangunan proyek high rise building sehingga perlu konsen dalam mengelola manajemen K3 .
PT. Bintai Kindenko Engineering Indonesia (Binkei) merupakan Affiliated Companies (Affco) PT. Acset Indonusa Tbk (Acset) Astra Group, adalah perusahaan yang bergerak di jasa konstruksi dan kontraktor dengan spesialisasi di bidang fondasi, struktur, sipil dan infrastruktur. Saat ini PT Binkei adalah salah satu kontraktor yang menangani langsung proyek konstruksi high rise building yaitu gedung Indonesia Satu Tower, spesialis dibidang engineering, mekanikal, elektrikal dan plumbing yang mana membawahi langsung beberapa sub kontraktor dalam pengerjaannya.

PT. Bintai Kindenko Engineering Indonesia (BINKEI), disebut sebagai Kontraktor, berkomitmen terhadap perlindungan karyawan, aset dan lingkungan serta reputasi. Rencana SHE proyek berkomitmen terhadap MK3LL melalui proses peningkatan berkesinambungan. Pelaksanaan Rencana SHE proyek ini akan menjamin keamanan, kesehatan dan kesejahteraan personil yang terlibat dalam semua kegiatan seluruh proyek. Melindungi aset dan peralatan untuk memastikan kelayakan ekonomi proyek. Pastikan semua 
kegiatan sesuai dengan undang-undang lokal, nasional dan internasional yang berlaku dan serta persyaratan rencana SHE Client.

PT. Bintai Kindenko Engineering Indonesia (BINKEI) telah berusaha untuk meningkatkan inti organisasi yang fokus pada proses bisnis manajemen, teknik dan manajemen keuangan. Manajemen eksekutif PT. Bintai Kindenko Engineering Indonesia (BINKEI) telah memimpin melalui profil profesional dengan pengalaman, pengetahuan dan jaringan yang mendalam dan luas pada proyek Mekanikal dan Elektrikal di wilayah Indonesia. Dengan dukungan yang kuat dari pemegang saham, PT. Bintai Kindenko Engineering Indonesia (BINKEI) berkembang dan terus meningkatkan Sistem Manajemen Mutu, Kompetensi dan Keterampilan agar dapat bersaing dalam persaingan pasar, sehingga dapat memberikan kontribusi yang tinggi terhadap proyek Mekanik dan Elektrikal di seluruh wilayah Indonesia. Membangun reputasi melalui peningkatan berkesinambungan terhadap kualitas kerja, kehandalan dan pelayanan agar tercapai dan melampaui harapan pelanggan. Dalam organisasi telah berkomitmen dan berusaha untuk memberikan keunggulan tenaga kerja berdasarkan fungsi dan tanggung jawabnya.

Sebagai perusahaan jasa engineering yang bergerak dalam bidang Mekanikal Elektrikal dan Plambing (MEP) pada proyek konstruksi building memberlakukan Manual Sistem Manajemen mengacu pada Standar Internasional, antara lain ISO 9001: 2015 (Mutu), ISO 14001:2015 (Lingkungan), dan OSHAS 18001:2017 (K3), sesuai dengan Undang-Undang No. 1/ 1970 dan Peraturan Pemerintah No. 50/ 2012 tentang Sistem Manajemen Keselamatan dan Kesehatan Kerja.; Kualitas, Keselamatan, Kesehatan Kerja dan Lingkungan tetap menjadi perhatian PT. Bintai Kindenko Engineering Indonesia (BINKEI). Hal ini terbukti dengan Standar Sertifikat Internasional, antara lain ISO 9001:2015 (Mutu), ISO 14001:2015
(Lingkungan), dan OSHAS 18001:2017 (K3). PT. Bintai Kindenko Engineering Indonesia (BINKEI) memiliki kerangka kerja yang menyeluruh untuk bidang K3LL yang memerlukan organisasi untuk mengatur operasionalnya dengan cara yang aman tanpa merusak lingkungan dan mengekspose pekerja terhadap risiko kecelakaan untuk mencegah bahaya-bahaya yang dapat menimbulkan penyakit akibat kerja dan masalah-masalah yang berhubungan dengan kesehatan.

Proyek pembangunan Indonesia Satu Tower atau Menara Indonesia Satu adalah sepasang menara kembar pencakar langit yang saat ini berlangsung pembangunannya berlokasi di Jalan M.H.Thamrin, Jakarta Pusat. Gedung pencakar langit Indonesia 1 Tower ini terdiri dari dua bangunan kembar yaitu Indonesia 1 Tower South dan Indonesia 1 Tower North (Shany, 2016).

Indonesia Satu Tower akan menjadi gedung multifungsi yang mencakup perkantoran, ruang ritel, kondominium, serta apartemen servis. Proyek ini mulai konstruksi pada tanggal 23 Mei 2015 di dibangun diatas lahan dengan luas 18.925 M2 dengan mengusung nama "Indonesia Satu". Gedung "Indonesia Satu" untuk Tower 1 terencana mempunyai 57 lantai diatas permukaan tanah dan 7 lantai basement (dibawah permukaan tanah) sedangkan untuk Tower 2 direncanakan memiliki 63 lantai diatas permukan tanah dan 7 lantai basement (dibawah permukaan tanah) dengan ketinggian gedung mencapai 303,5 m untuk Tower 1 dan ketinggian 306 m untuk Tower 2.

Berdasarkan (Irawan, 2020) bangunan konstruksi high rise building ini diperkirakan akan selesai pekerjaannya ditahun 2020 . Namun di awal tahun 2020 ini pekerjaan proyek terhambat dikarenakan adanya pandemic Covid-19 dan sebagian pekerja di rumahkan (work from home) demi menjaga dan mencegah penyebaran Virus Covid-19, 
langkah-langkah preventif pun sudah dilakukan di proyek tersebut seperti: pengecekan suhu tubuh, dan sterilisasi area dengan disinfektan, fogging serta pemberian supplemen imun kepada semua pekerja proyek sesuai dengan protokol pencegahan Covid-19 di proyek konstruksi (KemenPUPR- Protokol-Pencegahan-COVID-19-diProyek-Konstruksi). Namun masih ada hal lain yang perlu diperhatikan dalam melakukan aktifitas pekerjaan yang dilakukan oleh pekerja sehingga dapat mencegah terjadinya kecelakaan kerja di proyek.

Sistem manajemen K3 adalah bagian dari sistem manajemen perusahaan secara keseluruhan yang dibutuhkan bagi pengembangan, penerapan, pencapaian, pengkajian dan pemeliharaan kewajiban K3, dalam rangka pengendalian risiko yang berkaitan dengan kegiatan kerja guna terciptanya tempat kerja yang aman, efisien, dan produktif (KERJA \& INDONESIA, 2017).

Tujuan penerapan sistem manajemen kesehatan dan keselamatan kerja (SMK3) (Pangkey et al., 2012) dalam rangka (1) Untuk meningkatkan efektivitas perlindungan K3 dengan cara : terencana, terukur, terstruktur terintegrasi dan (2) Untuk mencegah kecelakaan kerja dan mengurangi penyakit akibat kerja, dengan melibatkan: manajemen, tenaga kerja/pekerja dan serikat pekerja (Noviandini et al., 2017).

Kecelakaan nihil adalah suatu kondisi tidak terjadi kecelakaan di tempat kerja yang mengakibatkan pekerja sementara tidak mampu bekerja (STMB) selama 2 × 24 jam, menyebabkan terhentinya proses dan atau rusaknya peralatan tanpa korban jiwa dimana kehilangan waktu kerja tidak melebihi shift berikutnya pada kurun waktu tertentu dan jumlah jam kerja orang tertentu (Korneilis \& Gunawan, 2018).

Faktor personal adalah faktor-faktor yang timbul dari dalam individu. Faktor personal memiliki peran dalam menentukan interaksi sosial dalam membentuk perilaku individu. Faktor personal merupakan salah satu sebab atau faktor yang mendasari kejadian kecelakaan dan berasal dari manusia atau para pekerjanya sendiri (Dwipayana et al., 2018).

Semua pekerja proyek Indonesia Satu Tower ini selain pekerja local (warga negara Indonesia) ada sebagian pekerja dari negara China (TKA) dikarenakan pemilik saham nya adalah gabungan dari dua perusahaan asal negara China dan Indonesia (Hennida et al., 2020). Struktur bangunan proyek yang begitu rumit dan komplek tentunya potensi bahaya dan risiko kecelakaan semakin tinggi sehingga banyak pekerja proyek yang mengalami kecelakaan kerja baik kecelakaan kerja ringan bahkan sampai kecelakaan kerja berat. Dari data kecelakan kerja di proyek tersebut ada yang terlaporkan dan ada juga yang tidak terlaporkan kepada BPJS ketenaga kerja

Tabel 2

Jumlah Kecelakaan Kerja akibat Faktor Manusia dan Faktor Lingkungan di Proyek Indonesia Satu Tower 2018-2020

\begin{tabular}{|c|c|c|c|c|c|c|}
\hline \multirow[b]{2}{*}{ No } & \multirow[b]{2}{*}{ Penyebab Kecelakaan Kerja } & \multicolumn{5}{|c|}{ Jumlah Kecelakaan Kerja } \\
\hline & & $\begin{array}{l}\text { Tahun } \\
2018\end{array}$ & & $\begin{array}{l}\text { Tahun } \\
2019\end{array}$ & & $\begin{array}{l}\text { Tahun } \\
2020\end{array}$ \\
\hline 1. & Faktor manusia* & 5 & 3 & & 0 & \\
\hline 2. & Faktor lingkungan* & 0 & 1 & & 0 & \\
\hline & Total & 5 & 4 & & 0 & \\
\hline
\end{tabular}



Dari informasi (Endroyo \& Tugino, 2009) yang didapat bahwa kecelakaan kerja pada proyek konstruksi banyak disebabkan dari faktor tindakan tidak aman, data kecelakaan kerja tersebut diambil dari periode proyek tahun $2018 \mathrm{~s} / \mathrm{d} 2020$, dari tabel tersebut terdapat penurunan kecelakaan kerja di tahun 2019 dibandingkan tahun 2018 penurunan tersebut tidak signifikansi (tidak terpaut jauh) dan pada tahun 2020 mengalami penurunan belum terjadi kecelakaan dikarenakan turunnya aktifitas pekerjaan proyek.

Oleh sebab itu, kejadian kecelakaan kerja pada proyek konstruksi di gedung Indonesia Satu Tower sedikit atau banyaknya telah memakan korban kecelakaan kerja selama proyek berlangsung, peneliti bertujuan untuk menganalisa langsung hubungan dan pengaruh penyebab terjadinya kecelakaan kerja yang disebabkan tindakan tidak aman (unsafe action) sehingga peneliti dapat menyimpulkan judul penelitian ini adalah "Analisa Hubungan Faktor Personal dan Manajemen K3 terhadap Tindakan Tidak Aman dan Kecelakaan Kerja pada Proyek Konstruksi Indonesia Satu Tower (PT. Bintai Kindenko Engineering Indonesia)".

Tujuan penelitian ini yaitu untuk menganalisa dan mengetahui Pengaruh Faktor Personal dan Manajemen K3 terhadap Tindakan Tidak Aman dan Kecelakaan Kerja pada Proyek Konstruksi Indonesia Satu Tower (PT. Bintai Kindenko Engineering Indonesia).

Penelitian ini sejalan dengan (Hafrida, 2014) Faktor personal berupa pengetahuan K3 memiliki pengaruh negatif yang signifikan terhadap tindakan tidak aman (unsafe action). Faktor personal berupa pelatihan K3 memiliki pengaruh negatif yang signifikan terhadap tindakan tidak aman (unsafe action). Faktor personal berupa beban kerja memiliki pengaruh negatif yang signifikan terhadap tindakan tidak aman (unsafe action). Faktor personal berupa kelelahan memiliki pengaruh negatif yang signifikan terhadap tindakan tidak aman (unsafe action). Manajemen K3 memiliki pengaruh negatif yang signifikan terhadap tindakan tidak aman (unsafe action)

\section{Metode Penelitian}

Dalam penelitan ini penulis menggunakan metode pendekatan secara kuantitatif. Metode kuantitatif adalah metode penelitian yang dapat diartikan sebagai metode penelitan yang berlandaskan pada filsafat positivisme, digunakan untuk meneliti pada populasi atau sampel tertentu, pengumpulan data menggunakan instrumen penelitian, analisis data bersifat kuantitatif dengan tujuan untuk menguji hipotesis yang telah ditetapkan (Sugiyono, 2016).

Penelitian ini termasuk penelitian lapangan (field research), yaitu penelitian yang bertujuan untuk mempelajari secara intensif tentang latar belakang keadaan sekarang dan interaksi lingkungan suatu unit sosial baik individu, kelompok, lembaga, atau masyarakat (Mulyatiningsih \& Nuryanto, 2014).

Metode yang digunakan dalam penelitian ini adalah metode survei yaitu metode (penelitian) yang menggunakan kuesioner sebagai instrumen utama untuk mengumpulkan data (Sugiyono, 2016).

Atas dasar hal itu, maka penulis berkesimpulan bahwa pendekatan kuantitatif dengan tingkat pengaruh dan metode survei cocok digunakan dalam penelitian ini untuk mengetahui pengaruh lebih dari satu variabel, yaitu satu variabel eksogen yaitu faktor personal (X1), manajemen K3 (X2) dan variabel endogen yaitu tindakan tidak aman (Y) dan kecelakaan kerja (Z).

\section{Hasil dan Pembahasan}

Dalam penelitian ini pengolahan data menggunakan program PLS dengan menggunakan metode partial least square yang dilakukan dengan tiga tahap yaitu: (1) 
Analisa Outer Model, (2) Analisa Inner Model, dan (3) Pengujian hipotesis.

1. Model Pengukuran (Outer Model)

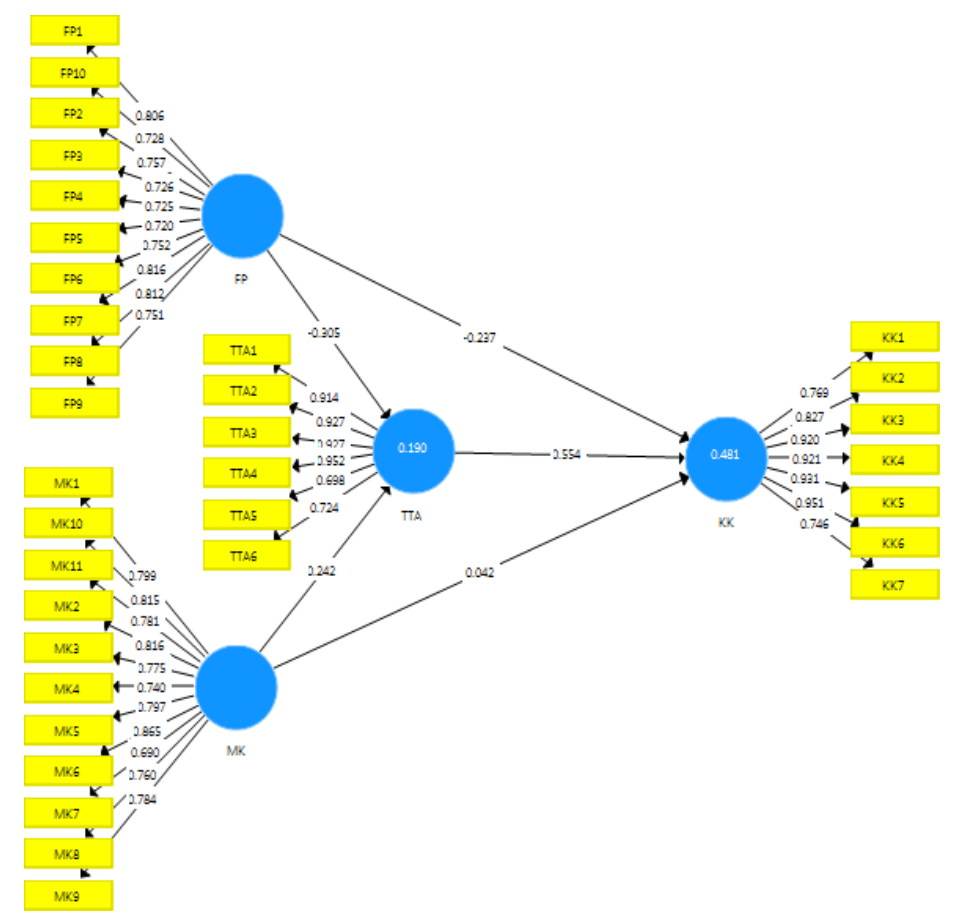

Sumber: Data diolah (2021)

Gambar 1. Hasil estimasi model PLS (Algorithm)

Berdasarkan hasil estimasi yang outer loading untuk variabel faktor personal ditampilkan pada Gambar 1 didapatkan hasil yaitu sebagai berikut :

Tabel 3

Hasil Outer Loading

\begin{tabular}{|c|c|c|c|c|}
\hline \multirow{2}{*}{ No } & Faktor & Manajemen & Tindakan Tidak & Kecelakaan \\
\hline & Personal & $\mathrm{K} 3$ & Aman & Kerja \\
\hline 1 & 0,806 & 0,799 & 0,914 & 0,769 \\
\hline 2 & 0,757 & 0,816 & 0,927 & 0,827 \\
\hline 3 & 0,726 & 0,775 & 0,927 & 0,920 \\
\hline 4 & 0,725 & 0,740 & 0,952 & 0,921 \\
\hline 5 & 0,720 & 0,797 & 0,698 & 0,931 \\
\hline 6 & 0,752 & 0,865 & 0,724 & 0,951 \\
\hline 7 & 0,816 & 0,690 & - & 0,746 \\
\hline 8 & 0,812 & 0,760 & - & \\
\hline 9 & 0,751 & 0,784 & - & \\
\hline 10 & 0,728 & 0,815 & - & \\
\hline 11 & 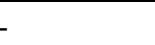 & 0,781 & - & \\
\hline
\end{tabular}

Keterangan : Valid jika masing-masing indikator variabel > 0,5

Sumber : Data diolah Smart PLS (2021) 

Berdasarkan Gambar 1 yang tertuang dalam Tabel 3 dapat diketahui bahwa masing- masing outer loading FP_1 sampai dengan outer loading FP_10 pada variabel Faktor Personal mendapatkan nilai angka outer loading berkisar antara 0,720 - 0,816, masing- masing outer loading MK_1 sampai dengan outer loading MK_11 pada variabel Manajemen K3 mendapatkan nilai angka outer loading berkisar antara 0,690 - 0,865, masing-masing outer loading TTA_1 sampai dengan outer loading TTA_6 pada variabel Tindakan Tidak Aman mendapatkan nilai angka outer loading berkisar antara 0,698 0,952 dan untuk masing-masing outer loading KK_1 sampai dengan outer loading KK_7 pada variabel Kecelakaan Kerja mendapatkan nilai angka outer loading berkisar antara 0,746 - 0,951, maka seluruh outer loading lebih besar dari 0,5 sehingga variabel dalam penelitian ini dinyatakan valid. Sehingga seluruh outer loading tersebut dapat dilakukan analisis selanjutnya.

4.2 Pengujian Model Struktural (Inner Model)

Berikut ini adalah inner model atau pengujian model struktural yang dapat dijelaskan bahwa uji goodness of fit model PLS (Partial Least Square) dapat dilihat dari nilai nilai Standardised root Mean square Residual Model (SMRM). Model PLS (Partial Least Square) dinyatakan telah memenuhi kriteria goodness of fit model jika nilai $\mathrm{SRMR}<0,10$ dan model dinyatakan perfect fit jika nilai SRMR $<0,08$.

\section{Tabel 4}

Hasil uji Goodness of Fit Model

\begin{tabular}{clr}
\hline Goodness Of Fit Model & Estimated Model & Ketentuan \\
\hline SRMR & 0,066 & $<0,08$ \\
\hline
\end{tabular}

Sumber: Data diolah Smart PLS (2021)

Berdasarkan Tabel 4 diperoleh hasil uji goodness of fit menunjukkan bahwa nilai Standardised root mean square residual (SRMR) model PLS (Partial Least Square) adalah sebesar 0,066. Oleh karena nilai SRMR model di bawah 0,08 maka penelitian ini menggunakan model PLS (Partial Least Square) dinyatakan fit, yang berarti penelitian ini sudah tepat dan layak digunakan untuk menguji hipotesis penelitian.

2. Pengujian Hipotesis

Hasil estimasi model sebagai acuan untuk menguji hipotesis dalam penelitian ini dapat dilihat pada Gambar berikut

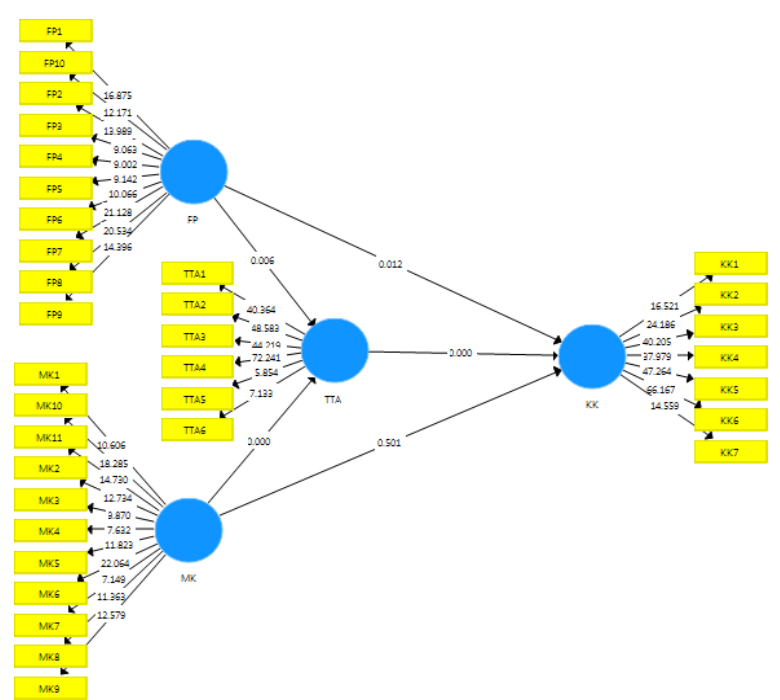

Sumber: Data diolah Smart PLS (2021)

Gambar 2. Hasil estimasi model PLS (Bootsrapping) 
Sementara itu untuk hasil perhitungannya dan pengaruh tidak langsung dapat dilihat berdasarkan pengaruh langsung

Tabel 5

Path Coefficient (Pengaruh Langsung)

\begin{tabular}{llll}
\hline \multicolumn{1}{c}{ Pengaruh langsung } & $\begin{array}{c}\boldsymbol{P} \text { - } \\
\text { Values }\end{array}$ & Ketentuan & Keterangan \\
\hline $\begin{array}{l}\text { Faktor Personal_FP terhadap } \\
\text { Tindakan Tidak Aman_TTA }\end{array}$ & 0,006 & $<0,05$ & Signifikan \\
\hline $\begin{array}{l}\text { Manajemen K3_MK terhadap } \\
\text { Tindakan Tidak Aman_TTA }\end{array}$ & 0,000 & $<0,05$ & Signifikan \\
\hline $\begin{array}{l}\text { Faktor Personal_FP terhadap } \\
\text { Kecelakaan Kerja_KK }\end{array}$ & 0,012 & $<0,05$ & Signifikan \\
\hline $\begin{array}{l}\text { Manajemen K3_MK terhadap } \\
\text { Kecelakaan Kerja_KK }\end{array}$ & 0,501 & $>0,05$ & Tidak \\
\hline
\end{tabular}

Sumber: Data diolah Smart PLS (2021)

Berdasarkan hasil perhitungan yang dirangkum pada Tabel 5. dapat dilihat signifikansi dari hasil p-value pada masingmasing variabel eksogen terhadap variabel endogen yaitu sebagai berikut :

1. Perolehan nilai $\mathrm{p}$-values sebesar $0,006<$ 0,05 , maka hipotesis diterima (H1 diterima). Sehingga dapat diketahui bahwa variabel Faktor Personal_FP terbukti berpengaruh secara signifikan terhadap Tindakan Tidak Aman_TTA pada Proyek Konstruksi Indonesia Satu Tower PT. Bintai Kindenko Engineering Indonesia.

2. Perolehan nilai p-values sebesar $0,000<$ 0,05 , maka hipotesis diterima $(\mathrm{H} 2$ diterima). Sehingga dapat diketahui bahwa variabel Manajemen K3_MK terbukti berpengaruh signifikan terhadap Tindakan Tidak Aman_TTA pada Proyek Konstruksi Indonesia Satu Tower PT. Bintai Kindenko Engineering Indonesia.

3. Perolehan nilai p-values sebesar $0,012<$ 0,05 , maka hipotesis diterima (H3 diterima). Sehingga dapat diketahui bahwa variabel Faktor Personal_FP terbukti berpengaruh signifikan terhadap Kecelakaan Kerja_KK pada Proyek
Konstruksi Indonesia Satu Tower PT. Bintai Kindenko Engineering Indonesia.

4. Perolehan nilai p-values sebesar 0,501 > 0,05, maka hipotesis ditolak (H4 ditolak). Sehingga dapat diketahui bahwa variabel Manajemen K3_MK tidak terbukti berpengaruh signifikan terhadap Kecelakaan Kerja_KK pada Proyek Konstruksi Indonesia Satu Tower PT. Bintai Kindenko Engineering Indonesia.

5. Perolehan nilai p-values sebesar $0,000<$ 0,05, maka hipotesis diterima (H5 diterima). Sehingga dapat diketahui bahwa variabel Tindakan Tidak Aman_TTA terbukti berpengaruh secara signifikan terhadap Kecelakaan Kerja_KK pada Proyek Konstruksi Indonesia Satu Tower PT. Bintai Kindenko Engineering Indonesia.

Adapun dari hasil indirect effect antara variabel eksogen terhadap variabel endogen, dapat dilihat sebagai berikut : 
Tabel 6

Indirect Effect (Pengaruh Tidak Langsung)

\begin{tabular}{lccl}
\hline \multicolumn{1}{c}{ Pengaruh tidak langsung } & $\begin{array}{c}\boldsymbol{P} \text { - } \\
\text { Values }\end{array}$ & Ketentuan & Keterangan \\
\hline $\begin{array}{l}\text { Faktor Personal_FP terhadap Kecelakaan } \\
\text { Kerja_KK melalui } \\
\text { Tindakan Tidak Aman_TTA }\end{array}$ & 0,017 & $<0,05$ & Signifikan \\
\hline $\begin{array}{l}\text { Manajemen K3_MK terhadap Kecelakaan } \\
\text { Kerja_KK melalui } \\
\text { Tindakan Tidak Aman_TTA }\end{array}$ & 0,005 & $<0,05$ & Signifikan \\
\hline
\end{tabular}

Sumber: Data diolah Smart PLS (2021)

Berdasarkan pada Tabel 6. dapat dilihat signifikansi pengaruh masing-masing variabel dengan melihat nilai koefisien parameter:

1. Perolehan nilai $\mathrm{p}$-values sebesar $0,005<$ 0,05, maka hipotesis diterima (H6 diterima). Sehingga dapat diketahui bahwa variabel Faktor Personal_FP terbukti berpengaruh signifikan terhadap Kecelakaan Kerja_KK melalui Tindakan Tidak Aman_TTA pada Proyek Konstruksi Indonesia Satu Tower PT. Bintai Kindenko Engineering Indonesia.

2. Perolehan nilai $\mathrm{p}$-values sebesar $0,005<$ 0,05, maka hipotesis diterima (H7 diterima). Sehingga dapat diketahui bahwa variabel Manajemen K3_MK terbukti berpengaruh signifikan terhadap Kecelakaan Kerja_KK melalui Tindakan Tidak Aman_TTA pada Proyek Konstruksi Indonesia Satu Tower PT. Bintai Kindenko Engineering Indonesia.

\section{Kesimpulan}

Berdasarkan hasil penelitian maka diperoleh hasil bahwa Variabel Faktor Personal_FP berpengaruh secara signifikan terhadap Tindakan Tidak Aman_TTA pada Proyek Konstruksi Indonesia Satu Tower PT. Bintai Kindenko Engineering Indonesia.

Variabel Manajemen K3_MK terbukti berpengaruh signifikan terhadap Tindakan Tidak Aman_TTA pada Proyek Konstruksi Indonesia Satu Tower PT. Bintai Kindenko Engineering Indonesia.
Variabel Faktor Personal_FP terbukti berpengaruh signifikan terhadap Kecelakaan Kerja_KK pada Proyek Konstruksi Indonesia Satu Tower PT. Bintai Kindenko Engineering Indonesia.

Variabel Manajemen K3_MK tidak terbukti berpengaruh signifikan terhadap Kecelakaan Kerja_KK pada Proyek Konstruksi Indonesia Satu Tower PT. Bintai Kindenko Engineering Indonesia.

Variabel Tindakan Tidak Aman_TTA terbukti berpengaruh secara signifikan terhadap Kecelakaan Kerja_KK pada Proyek Konstruksi Indonesia Satu Tower PT. Bintai Kindenko Engineering Indonesia.

\section{BIBLIOGRAFI}

Djatmiko, R. D. (2016). Keselamatan dan kesehatan kerja. Deepublish. Google Scholar

Dwipayana, N. E., Handoko, L., \& Setiani, V. (2018). Pengaruh faktor Personal terhadap Perilaku Keselamatan (Safety Behavior) Pekerja di Perusahaan Kereta Api. Seminar K3, 2(1), 535-540. Google Scholar

Endroyo, B., \& Tugino, T. (2009). Analisis faktor-faktor penyebab kecelakaan kerja konstruksi. Jurnal Teknik Sipil Dan Perencanaan, 9(1), pp-21. Google Scholar

Hafrida, E. (2014). Pengaruh Faktor Personal 
dan Manajemen K3 terhadap Tindakan Tidak Aman (Unsafe Action) pada Pekerja di PT. Inti Benua Perkasatama Dumai. Google Scholar

Hennida, C., Wardhana, A., Sahab, A., Saadah, K., Pratiwi, F. I., \& Ratmoko, E. (2020). Respons Negara-Negara Asia Tenggara Terhadap Dominasi China. Airlangga University Press. Google Scholar

Irawan, J. R. (2020). Studi kasus keberlanjutan proyek konstruksi bangunan gedung tinggi di Kota Bekasi $=$ Case study of sustainability in high-rise building construction projects in bekasi. Universitas Pelita Harapan. Google Scholar

KERJA, M. T., \& INDONESIA, R. (2017). Permenaker No. 5 Tahun 1996 tentang Sistem Manajemen Keselamatan dan Kesehatan Kerja.

Korneilis, K., \& Gunawan, W. (2018). Manfaat Penerapansistem Manajemen K3 Dalam Upaya Pencapaian Zero Accident Di Suatu Perusahaan. Jurnal Sistem Informasi Dan Informatika (Simika), 1(01), 84-104. Google Scholar

Mulyatiningsih, E., \& Nuryanto, A. (2014). Metode penelitian terapan bidang pendidikan. Google Scholar

Noviandini, S., Ekawati, E., \& Kurniawan, B.
(2017). Analisis Komitmen Pimpinan terhadap Penerapan Sistem Manajemen K3 (Smk3) di PT Krakatau Steel (Persero) tbk. Jurnal Kesehatan Masyarakat (Undip), 3(3), 639-650. Google Scholar

Pangkey, F., Malingkas, G. Y., \& Walangitan, D. R. O. (2012). Penerapan Sistem Manajemen Keselamatan dan Kesehatan Kerja (SMK3) Pada Proyek Konstruksi di Indonesia (Studi Kasus: Pembangunan Jembatan Dr. Ir. Soekarno-Manado). Jurnal Ilmiah Media Engineering, 2(2). Google Scholar

PI, S. M., Wiyono, J., \& Candrawati, E. (2017). Kejadian kecelakaan kerja perawat berdasarkan tindakan tidak aman. Care: Jurnal Ilmiah Ilmu Kesehatan, 3(2), 9-17. Google Scholar

Ramli, S. (2010). Sistem Manajemen Keselamatan \& Kesehatan Kerja. Google Scholar

Shany, A. M. (2016). Analisis Keterlambatan Tagihan Piutang Jasa Terhadap Penilaian Performa Dealler di PT. Nasmoco Abadi Motor. Google Scholar

Sugiyono. (2016). Metode Penelitian Pendidikan. Alfabeta CV. Google Scholar

\section{Copyright holder :}

Agus Komarudin, Kholil, Toto Hardiyanto (2022)

First publication right :

Jurnal Syntax Transformation

This article is licensed under:

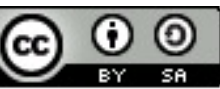

